\title{
Trivalent and Hexavalent Chromium Issues in Medical Implants
}

\author{
L.E. Eiselstein ${ }^{1, a}$, D.M. Proctor ${ }^{2, b}$, and T.C. Flowers ${ }^{1, c}$ \\ ${ }^{1}$ Exponent, Menlo Park, CA, USA \\ ${ }^{2}$ Exponent, Irvine, CA, USA

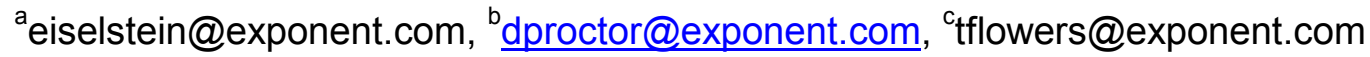

Keywords: Stainless steels, cobalt-chromium alloys, implantable medical devices, trivalent chromium, hexavalent chromium, passivation, toxicity

\begin{abstract}
Metal alloys containing chromium (Cr), primarily stainless steels and $\mathrm{CoCr}$ alloys, are used in a wide variety of implantable medical devices. These alloys are exposed to chloride containing environments with varying oxidizing potential and complexing agents. These corrosion assisted environmental effects may result in metal ions going into solution. The toxicity of $\mathrm{Cr}$ is dependent on valence state. Hexavalent $\mathrm{Cr}$ ions are recognized to be more toxic than trivalent $\mathrm{Cr}$. This paper discusses the state of knowledge regarding $\mathrm{Cr}$ release, the chemical and mechanical factors that most significantly affect $\mathrm{Cr}$ release, and the potential toxicity of $\mathrm{Cr}$ as it applies to longterm implantable medical devices.
\end{abstract}

\section{Introduction}

$\mathrm{Cr}$ is frequently used in many metal orthopedic implants. These alloys, when exposed to air and body fluids, will form an oxide/hydroxide barrier (containing $\mathrm{Cr}_{2} \mathrm{O}_{3}$ ). This barrier helps prevent further corrosion (passivation) and dissolution of the metallic substrate. This passive coating, however, can continue to dissolve and reform resulting in steady-state layer thickness with a small but potentially detectable amount of $\mathrm{Cr}$ ion release into surrounding tissue. This paper reviews what is currently known regarding the rate and nature of this dissolution and specifically look at the potential for these alloys to generate $\mathrm{Cr}$ in the hexavalent state $\left[\mathrm{Cr}(\mathrm{VI})\right.$ or $\left.^{\mathrm{Cr}}{ }^{+6}\right]$. $\mathrm{Cr}$ in solution under normal in-vivo conditions is more typically expected to be present in the trivalent form of $\mathrm{Cr}$

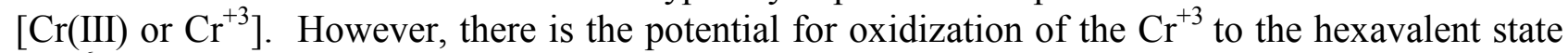
$\left(\mathrm{Cr}^{+6}\right)$ due to the further in-vivo oxidation of the orthopedic implant dissolution products.

\section{Corrosion and Passive Layer Characterization}

Metallic implants inserted into the body will eventually undergo some degradation by a variety of mechanisms, including abrasion and corrosion [1]. Many implant-grade alloys contain Cr. For example, CoCrMo alloys are more frequently being used for orthopedic implants because of their hardness, strength, and resistance to corrosion and wear. In particular, these alloys are now being selected for the new generation of metal-on-metal bearing couples [2].

The CoCrMo alloys have been widely regarded as having good biocompatibility in the body, even though studies have indicated that both particulate and soluble-wear debris is transported from the location of the implant to remote organs [2]. The $\mathrm{Cr}$ in these alloys is essential for forming a passive layer. This passive layer contains $\mathrm{Cr}_{2} \mathrm{O}_{3}$ or $\mathrm{Cr}(\mathrm{OH})_{3}$, as well as other alloying elements, and limits the rate of corrosion by restricting the transport of water, oxygen, and metal ions through the oxide/hydroxide film and/or the dissolution of the film itself. The free energy formation of $\mathrm{Cr}_{2} \mathrm{O}_{3}$ and $\mathrm{Cr}(\mathrm{OH})_{3}$ is more negative than for $\mathrm{Ni}$ or Fe oxides and hydroxides; therefore, is formed preferentially. The corrosion film that forms acts as a barrier that reduces the flow of species (electrons, holes, $\mathrm{Cr}^{+3}, \mathrm{Co}^{+2}, \mathrm{Fe}^{+2}, \mathrm{Ni}^{+2}, \mathrm{O}_{2}$, etc.) both ways across the interface [2]. By restricting the flow, the reaction rate is slowed.

Passive films formed on most metals and alloys behave as a thin semiconductor layer [3]. The passive film formed on a $\mathrm{Fe}-18 \% \mathrm{Cr}$ alloy in a slightly alkaline $(8.4 \mathrm{pH})$ borate buffer solution is 
composed of an inner layer of $\mathrm{Cr}_{2} \mathrm{O}_{3}$, and an outer hydroxide layer. Both layers are n-type semiconductors. In studies of stainless steels having an amorphous oxide film, the films show minimal interaction between the blood and amorphous oxide film [4,5]. Su and Shih report, through a proprietary process, the normally polycrystalline oxide layer can be removed and replaced with an amorphous n-type semiconductor layer with a higher $\mathrm{Cr}$ and $\mathrm{O}$ concentration. Hashimoto and Asami note that this highly protective amorphous oxide is a hydrated chromium oxyhydroxide $\left(\mathrm{CrO}_{\mathrm{x}}(\mathrm{OH})_{3-2 \mathrm{x}} \bullet \mathrm{nH}_{2} \mathrm{O}\right)$ and more protective than a crystalline one [4, 6]. Clayton and Olefjord report that shorter passivation times tend to favor formation of an amorphous film. With longer passivation times, some crystallization of the Cr oxide film is observed [7].

Thin passive films such as those present on stainless steel are not perfect. These films contain defects that can lead to pitting corrosion, particularly in the presence of chloride ions and in neutral or alkaline environments where the chromic oxide films can break down. Many contested models of pitting corrosion exist, but one undisputed aspect is that manganese sulfide inclusions play a critical role. Indeed, the vast majority of pitting events are found to occur at, or adjacent to, such second-phase particles. Cr-depleted zones are susceptible to high-rate dissolution that 'triggers' pitting [8].

Lewis et al. have recently reported on the corrosion and dissolution of high- and low-carbon CoCrMo alloys, used in orthopedic joint replacements in three different environments: phosphatebuffered saline (PBS), water, and synovial fluid [2]. Release of ions into solution from the alloy showed that the synovial fluid had the highest $\mathrm{Cr}$ concentration but the lowest Co concentration relative to the water and PBS solution. They determined that proteins that form films assist $\mathrm{Cr}$ dissolution, increasing $\mathrm{Cr}$ concentration in synovial fluid.

\section{In-Vivo Environment}

Although the body environment can be described by fairly constant conditions, anatomical location, and small differences in it, can have an important effect on the $\mathrm{pH}$ and $\mathrm{pO}_{2}$ which can have a significant influence on corrosion and dissolution of implant materials [9, 10]. The corrosion of implants can be influenced by numerous factors that may not be completely accounted for in a simple thermodynamic analysis. The most important of these is oxygen, whose partial pressure within the body is widely variable from about $2.7 \times 10^{2}$ to $1.33 \times 10^{4} \mathrm{~Pa}(0.003$ to $0.13 \mathrm{~atm})$ [11, 12].

The $\mathrm{pH}$ in the body is normally regulated at about 7.4 , but in certain circumstances, the value may be quite different. At sites of inflammation there is a transient "acid tide" in which the pH may fall to as low as 4.5 for periods of hours, or longer [12]. Merritt and Brown have noted that the inflammatory response of tissue to an implant, and infection, may lower the $\mathrm{pH}$; hence, increase corrosion, as well as affecting the metal binding to proteins in the serum, synovial fluid, and cells [1]. In addition to inflammation, carbon dioxide levels in body fluid can have an influence on invivo $\mathrm{pH}$. The effect of $\mathrm{CO}_{2}$ on $\mathrm{pH}$ is even more important for in-vitro testing particularly when the synthetic test solutions are not buffered [12].

Body cells can affect alloy corrosion in the body by changing the local chemical environment. They do this by releasing chemical compounds, depositing proteins, changing local $\mathrm{pH}$, limiting oxygen diffusion, or providing higher than normal oxidizing potentials from the reactive chemical species (RCS) [13-15]. Coury noted that both polymorphonuclear leukocytes (PMN) and macrophages metabolize oxygen to form a superoxide anion [16]. This intermediate can undergo transformation to more powerful oxidants, such as hydrogen peroxide, which can be converted to hypochlorous acid $(\mathrm{HOCl})$ resulting in low $\mathrm{pH}$ and high oxidizing potential at the implant site.

Low $\mathrm{pH}$ and high oxidizing potential can have a significant effect on the amount and nature of $\mathrm{Cr}$ dissolution. These direct oxidation processes occur normally during acute implant periods in which a burst of PMN activity, followed by macrophage activity, normally stops after a few weeks. 
However, because medical implants are normally present for long periods, a sustained attempt to phagocytize (digest) the implant occurs and can result in prolonged release of chemicals at the implant surface. This phenomenon in which macrophage-foreign body giant cells (FBGC) release these oxidizing chemicals is called exocytosis and occurs over months to possibly years and can contribute to long-term chemical degradation of implant materials [17-19].

Lin et al. also noted that macrophage cells lower local tissue $\mathrm{pH}$ and release RCS, such as NO, $\mathrm{H}_{2} \mathrm{O}_{2}$, and $\mathrm{O}_{2}^{-}$during wound healing and tissue remodeling which may alter alloy surfaces and affect CoCrMo alloy's corrosion properties. These corrosion products could then change the macrophage cell behavior $[13,14,20]$. Their data support the hypothesis that macrophage cells and their RCS affect alloy corrosion and that changes in alloy corrosion by cells may be important in the development of host responses to the alloy and its corrosion products.

Activated macrophage cells do not always increase the corrosion rate of implant alloys. Lin reports that the work of Parker et al. indicate that activated macrophage cells can actually decrease the corrosion rate of $316 \mathrm{~L}$ stainless steel $[5,13,21]$. The decreased corrosion was attributed to an enhancement of the alloy's oxide film by the released oxidizing compounds. Sundgren observed similar oxide thickening on retrieved well-functioning stainless steel implants [22].

\section{Thermodynamics of Dissolution}

At the $\mathrm{pH}$ of blood in the human body, chromic oxide has a solubility of approximately $10^{-11} \mathrm{~g} / \mathrm{L}$ at a temperature of $25^{\circ} \mathrm{C}$ in solutions not containing chloride, as seen in Fig. $1 . \mathrm{Cr}^{+3}$ solubility is enhanced in solutions containing chlorides, fluorides, sulfates, ammonium salts, cyanides, sulphocyanides, oxalates, and citrates $[23,24]$. In solutions containing chloride, $\mathrm{Cr}^{+3}$ has a solubility of approximately $10^{-6} \mathrm{~g} / \mathrm{L}$ at a temperature of $25^{\circ} \mathrm{C}$, as seen in Fig. $2 . \mathrm{Cr}^{+3}$ is expected to be slightly more soluble at the higher temperature of the human body. Although unlikely given the very low solubility of chromic oxide, it is possible that minute amounts of $\mathrm{Cr}^{+3}$ in solution could be liberated from the surface of the implant coating and participate in liquid-phase oxidation processes.

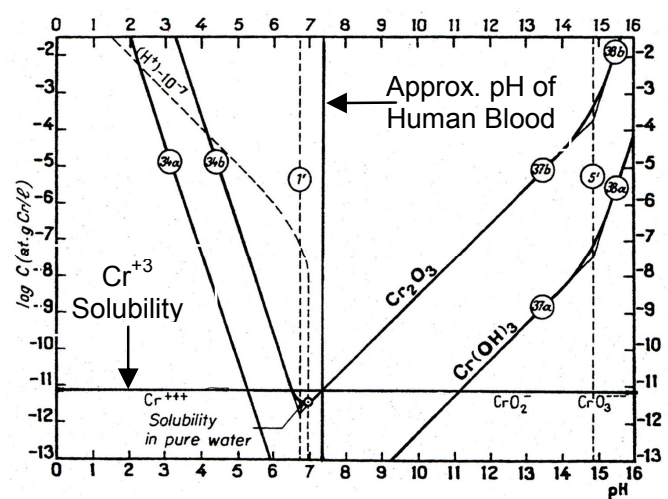

Fig. 1. Influence of $\mathrm{pH}$ on the solubility of $\mathrm{Cr}_{2} \mathrm{O}_{3}$ and $\mathrm{Cr}(\mathrm{OH})_{3}$ at $25^{\circ} \mathrm{C}[23,24]$.

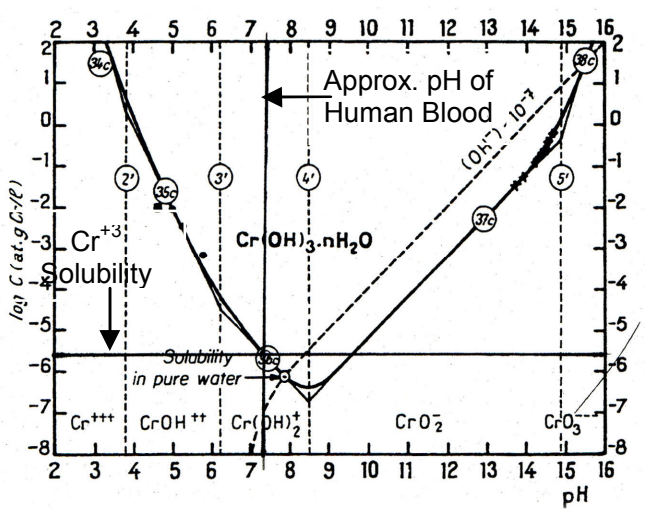

Fig. 2. Influence of $\mathrm{pH}$ on the solubility of hydrated $\mathrm{Cr}(\mathrm{OH})_{3}$ at $25^{\circ} \mathrm{C}$ in solutions containing chloride $[23,24]$.

To consider whether soluble $\mathrm{Cr}^{+3}$ could be oxidized in the liquid phase, a simplified thermodynamic evaluation of $\mathrm{Cr}^{+3}$ oxidation was conducted. Obviously, in-vivo environments are considerably more complex than a simple oxygenated aqueous environment, and as such, the following analysis may not accurately represent the potential for $\mathrm{Cr}^{+6}$ formation. For example, organometallic complexes can form and are not accounted for in a normal potential-pH diagram [11]. Such complex formation could significantly influence the solubility curves shown on the 
Pourbaix diagrams. Nevertheless, the thermodynamic approach is an excellent starting point to evaluate the potential for $\mathrm{Cr}^{+6}$ formation.

The most likely mechanism by which $\mathrm{Cr}^{+6}$ can be formed is via oxidation of the $\mathrm{Cr}^{+3}$ oxide coating or of $\mathrm{Cr}^{+3}$ that has been solubilized from the implant is provided in Eq. 1 [23, 24]:

$$
\begin{gathered}
\mathrm{Cr}_{2} \mathrm{O}_{3(s)}+5 \mathrm{H}_{2} \mathrm{O} \leftrightarrow 2 \mathrm{CrO}_{4}^{2-}+10 \mathrm{H}^{+}+6 e^{-} \\
E=E^{0}-0.103 p H+0.0205 \log \left(\mathrm{CrO}_{4}^{2-}\right)
\end{gathered}
$$

where $\mathrm{E}$ is the reduction/oxidation (redox) potential referenced to the standard hydrogen electrode (SHE) at $37^{\circ} \mathrm{C}$ and $1 \mathrm{~atm}$, and $\mathrm{E}^{0}$ is the redox potential referenced to the SHE at standard conditions (assuming the standard redox potential at $37^{\circ} \mathrm{C}$ is equal to the redox potential at $25^{\circ} \mathrm{C}$ ). The value of the redox potential under standard conditions, $\mathrm{E}^{0}$, will be dependent upon the form of $\mathrm{Cr}^{+3}$ in the film.

The redox potentials listed in Reference [23] were corrected to a temperature of $37^{\circ} \mathrm{C}$ and a $\mathrm{pH}$ of 7.4, the approximate $\mathrm{pH}$ of human blood. Aqueous species activities were assumed to be $10^{-9} \mathrm{moles} / \mathrm{L}$, the limit of detection for $\mathrm{Cr}^{+6}$ in water.

The oxidation power of blood is primarily controlled by the dissolved oxygen content, which is approximately $0.13 \mathrm{~atm}$ for arterial blood [25]. The dissolved oxygen reduction half-reaction [23, 24] is:

$$
\mathrm{O}_{2}+4 \mathrm{H}^{+}+4 e^{-} \leftrightarrow 2 \mathrm{H}_{2} \mathrm{O}
$$

and, assuming a standard redox potential of $1.229 \mathrm{~V}$, the temperature-corrected redox potential is:

$$
\begin{aligned}
E & =E^{0}-0.0615 p H+0.0154 \log \left(p_{O_{2}}\right) \\
& =0.76 \text { volts }
\end{aligned}
$$

From a thermodynamic standpoint, oxidation of $\mathrm{Cr}(\mathrm{OH})_{3} \bullet \mathrm{nH}_{2} \mathrm{O}$, the more easily oxidized form of $\mathrm{Cr}^{+3}$, via Eq. 1 was identified as the most likely pathway for oxidation of solid-phase $\mathrm{Cr}^{+3}$. This half-reaction has a lower potential $(\mathrm{E}=0.359 \mathrm{~V})$ than the reduction half-reaction in Eq. $2(\mathrm{E}=$ $0.76 \mathrm{~V}$ ), indicating that oxygen (the oxidant) can theoretically oxidize solid $\mathrm{Cr}^{+3}$ (the reductant) via this mechanism.

The other potential pathway for formation of $\mathrm{Cr}^{+6}$ is liquid-phase oxidation of $\mathrm{Cr}^{+3}$. The corrected redox potentials for all the reaction pathways listed in Reference [23] are all less than the redox potential of the oxygen reduction reaction, indicating that it is thermodynamically possible for these reactions to occur in the body. These basic calculations are consistent with the published findings of Merritt and Brown [26, 27] who reported $\mathrm{Cr}^{+6}$ could be produced through corrosion of $\mathrm{CoCr}$ and stainless steel implants in the body. These authors concluded $\mathrm{Cr}^{+6}$ released from the implant is rapidly reduced to $\mathrm{Cr}^{+3}$ in red blood cells (RBC). Bundy notes that Pourbaix diagrams show that $\mathrm{Cr}$ may exist in either trivalent or hexavalent form for the potential $/ \mathrm{pH}$ ranges expected in-vivo [12].

\section{$\mathrm{Cr}^{+3}$ and $\mathrm{Cr}^{+6}$ from In-Vivo Chromium or Chromia Dissolution}

While $\mathrm{Cr}$ can exist in valences ranging from -2 to +6 , in biological conditions the trivalent state $(+3)$ is the most stable [3]. The potential for $\mathrm{Cr}$ to pose a health hazard is highly dependent on both valence and solubility. $\mathrm{Cr}^{+3}$ is an essential micronutrient necessary for proper glucose metabolism and has an estimated mean adequate intake level of $35 \mu \mathrm{g} /$ day for males and $25 \mu \mathrm{g} /$ day for females [28]. $\mathrm{Cr}^{3+}$ displays relatively low toxicity via all routes of human exposure and is not considered to pose a carcinogenic hazard [29-31]. In contrast, because of its strong oxidizing potential and ability 
to be absorbed by biological tissues, $\mathrm{Cr}^{+6}$ is considered more toxic, and a human respiratory carcinogen when inhaled [32]. Despite it's genotoxicity, $\mathrm{Cr}^{+6}$ has not been shown to cause cancer upon oral or dermal exposure in animals or humans or outside the respiratory system [1]. Detoxification by relatively rapid reduction of $\mathrm{Cr}^{+6}$ to the trivalent state in most biological systems and conditions is believed to be the primary reason why $\mathrm{Cr}^{+6}$ does not pose a cancer hazard outside of the lung $[33,34]$.

Merritt and Brown conducted experiments to determine whether $\mathrm{Cr}^{+6}$ was released during corrosion of orthopedic implants [27]. Uptake of Cr by cells, and separation using amberlite resin, were the methods used to determine whether $\mathrm{Cr}^{+6}$ was present. The use of this method was further verified by the observation that only $\mathrm{Cr}^{+6}$ associated with $\mathrm{RBC}$ and most of $\mathrm{Cr}$ was intracellular and in the trivalent state - as expected from kinetics of $\mathrm{Cr}$ in blood. Their work suggests that $\mathrm{Cr}$ containing alloy implants can lead to the release of $\mathrm{Cr}^{+6}$ in the body, and that $\mathrm{Cr}^{+6}$ is rapidly reduced to $\mathrm{Cr}^{+3}$ inside the cells.

These observations are consistent with those of Corbett et al. [35] who examined the time- and concentration-dependent changes in the distribution of $\mathrm{Cr}^{+6}$ and total $\mathrm{Cr}$ in reconstituted human blood following addition of potassium dichromate. Fresh blood from human volunteers was collected from fasting individuals and individuals who had just eaten. This study [35] reported the reduction capacity of $\mathrm{RBC}$ is not overwhelmed at concentrations up to $15 \mathrm{ppm}$, and plasma reduction capacity ranges from 2 to $10 \mathrm{ppm}$. Hence, $\mathrm{RBC}$ and plasma have a tremendous capacity to reduce $\mathrm{Cr}^{+6}$ to $\mathrm{Cr}^{+3}$, which acts as a protective mechanism detoxifying any $\mathrm{Cr}^{+6}$ that may be released from implants. For these reasons, any $\mathrm{Cr}^{+6}$ that maybe generated through the wear of implants is expected be very short lived and not circulated widely through the body.

Although immune and inflammatory responses involving an attack of the local tissues and bone have been linked to adverse outcomes including the formation of foreign body giant cells, swelling, tissue necrosis, as well as aseptic loosening, there remains much dispute over the extent to which particular metals and their valences may result in complications and intolerance to metal implants.

\section{Conclusions}

We summarize with the following conclusions:

- Thermodynamic considerations, using the worst-case in-vivo conditions of low $\mathrm{pH}$ and high oxidizing potential, indicate there is the potential for $\mathrm{Cr}^{+6}$ generation.

- Discerning the valence of $\mathrm{Cr}$ released due to implant wear maybe of limited biological and health importance. Both valences of $\mathrm{Cr}$, as well as other elements released through implant corrosion, such as $\mathrm{Ni}$ and $\mathrm{Co}$, are associated with immunological and inflammatory responses. Most data regarding the valence state of $\mathrm{Cr}$ released as a result of corrosion and wear of metallic implants alloyed with $\mathrm{Cr}$ is indirect (cell binding suggestive of $\mathrm{Cr}^{+6}$ release). This evidence also suggests that if $\mathrm{Cr}^{+6}$ is actually present, it is only present for a very limited time, consistent with expected in-vivo kinetics of $\mathrm{Cr}^{+6}$, which is rapidly reduced to the trivalent state within blood.

\section{References}

1. Merritt, K. and S.A. Brown, "Biological Effects of Corrosion Products from Metals," Corrosion and Degradation of Implant Materials, Second Symposium, A.C. Fraker and C.D. Griffin, Editors. 1985, ASTM Louisville, KY. pp. 195-207.

2. Lewis, A.C., et al., J Biomed Mater Res A, 2005. 73(4): p. 456-67.

3. Tsuchiya, H., S. Fujimoto, and T. Shibata, Journal of the Electrochemical Society, 2004. 151(2): p. B29-B44.

4. Shih, C., et al., Wire Journal International, 2004(October): p. p. 64-69. 
5. Shih, C.C., et al., J Biomed Mater Res, 2000. 52(2): p. 323-32.

6. Hashimoto, K. and K. Asami, Corrosion Science, 1979. 19(4): p. 251-260.

7. Clayton, C. and I. Olefjord, Chapter 7: Passivity of Austenitic Stainless Steels, in Corrosion Mechanisms in Theory and Practice, P. Marcus (ed.), 2002, Marcel Dekker, Inc.:New York.

8. Ryan, M.P., et al., Nature, 2002. 415(6873): p. 770-4.

9. Morita, M., et al., Ann Biomed Eng, 1992. 20(5): p. 505-16.

10. Oron, U. and A. Alter, Clin Orthop Relat Res, 1984(185): p. 295-300.

11. Black, J., Biological Performance of Materials - Fundamentals of Biocompatibility. 1999, New York: Marcel Dekker, Inc.

12. Bundy, K.J., In-Vivo, in Corrosion Tests and Standards: Application and Interpretation, R. Baboian (ed.), 1995, ASTM: Philadelphia, PA.

13. Lin, H.Y. and J.D. Bumgardner, J Orthop Res, 2004. 22(6): p. 1231-1236.

14. Lin, H.Y. and J.D. Bumgardner, Biomaterials, 2004. 25(7-8): p. 1233-1238.

15. Lin, H.Y. and J.D. Bumgardner, J Biomed Mater Res A, 2004. 68(4): p. 717-24.

16. Coury, A.J., et al., Degradation of Materials in the Biological Environment, in Biomaterials Science: An Introduction to Materials in Medicine, B.D. Ratner, et al. (eds.), 1996, Academic Press: San Diego, CA.

17. Zhao, Q., et al., J Biomed Mater Res, 1990. 24(5): p. 621-37.

18. Zhao, Q., et al., J Biomed Mater Res, 1995. 29(4): p. 467-75.

19. Zhao, Q., et al., J Biomed Mater Res, 1991. 25(2): p. 177-83.

20. Catelas, I., et al., J Biomed Mater Res, 2004. 70B(2): p. 167-78.

21. Parker, S.H., et al., "Influence of Macrophage Cells on 316L Stainless Steel Corrosion," Stainless Steels for Medical and Surgical Applications, 2003. ASTM STP 1438.

22. Sundgren, J.E., et al., J Biomed Mater Res, 1985. 19(6): p. 663-71.

23. Pourbaix, M., Atlas of Electrochemical Equilibria in Aqueous Solutions. 1974, Houston, TX: NACE.

24. Pourbaix, M., Biomaterials, 1984. 5(3): p. 122-34.

25. Marek, M. "Oxygen and pH control in corrosion testing of surgical implants," Medical Device Materials: Proceedings from the Materials and Processes for Medical Devices Conference. 2003. Anaheim, CA: ASM International.

26. Brown, S.A., et al., J Appl Biomater, 1995. 6(1): p. 19-26.

27. Merritt, K. and S.A. Brown, J Biomed Mater Res, 1995. 29(5): p. 627-33.

28. National Academy of Science, Chapter 6, Dietary Reference Intakes for Vitamin A, Vitamin K, Arsenic, Boron, Chromium, Copper, Iodine, Iron, Manganese, Molybdenum, Nickel, Silicon, Vanadium, and Zinc. 1991, National Academy Press: Washington, DC. p. 6.

29. Agency for Toxic Substances and Disease Registry, Toxicological profile of chromium. 2000, Atlanta, GA: US Department of Health and Human Services.

30. International Agency for Research on Cancer, Monographs on the evaluation of carcinogenic risks to humans: Chromium, nickel and welding. 49. 1990, Lyon, France: World Health Organization.

31. US Environmental Protection Agency, Toxicological review of hexavalent chromium. 1998, Washington, DC: US Environmental Protection Agency.

32. National Toxicology Program, Report on carcinogens. 11th ed. 2005: US Department of Health and Human Services, Public Health Service.

33. De Flora, S., Carcinogenesis, 2000. 21: p. 533-541.

34. Proctor, D.M., et al., J. Toxicol. Environ. Health, 2002. Part A(65): p. 701-746.

35. Corbett, G.E., et al., Environ. Research. Sect. A, 1998. 78: p. 7-11. 